\title{
Contrasting effects of fire frequency on plant traits of three dominant perennial herbs from Chaco Serrano
}

\author{
Lucas M. Carbone
}

Ramiro Aguilar

Austral Ecology : a journal of ecology in the Southern Hemisphere. Vol. 41, No. 7 (2006), pp. 778-790 https://onlinelibrary.wiley.com/doi/full/10.1111/aec.12364

Este documento está disponible para su consulta y descarga en RDU (Repositorio Digital de la Universidad Nacional de Córdoba). El mismo almacena, organiza, preserva, provee acceso libre y da visibilidad a nivel nacional e internacional a la producción científica, académica y cultural en formato digital, generada por los miembros de la Universidad Nacional de Córdoba. Para más información, visite el sitio https://rdu.unc.edu.ar/

Esta iniciativa está a cargo de la OCA (Oficina de Conocimiento Abierto), conjuntamente con la colaboración de la Prosecretar ia de Informática de la Universidad Nacional de Córdoba y los Nodos OCA. Para más información, visite el sitio http://oca.unc.edu.ar/

\section{Cita del documento:}

Carbone, Lucas Manuel; Aguilar, Ramiro; Contrasting effects of fire frequency on plant traits of three dominant perennial herbs from Chaco Serrano; Wiley Blackwell Publishing, Inc; Austral Ecology; 41; 7; 2-2016; 778-790

Esta obra está bajo una Licencia Creative Commons Atribución-NoComercial-Compartirlgual 4.0 Internacional.

El Repositorio Digital de la Universidad Nacional de Córdoba (RDU), es un espacio donde se almacena, organiza, preserva, provee acceso libre y procura dar visibilidad a nivel nacional e internacional, a la producción científica, académica y cultural en formato digital , generada por los integrantes de la comunidad universitaria.
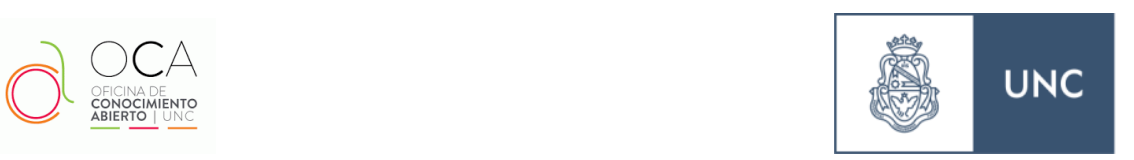

Universidad

Nacional

de Córdoba 


\title{
Contrasting effects of fire frequency on plant traits of three dominant perennial herbs from Chaco Serrano
}

\author{
LUCAS M. CARBONE ${ }^{1,2 \star}$ and RAMIRO AGUILAR ${ }^{3}$ \\ ${ }^{1}$ Herbario ACOR, Facultad de Ciencias Agropecuarias, Universidad Nacional de Córdoba (Email: lcarbone@agro. \\ unc.edu.ar), ${ }^{2}$ Consejo Nacional de Investigaciones Científicas y Técnicas (CONICET) and ${ }^{3}$ Instituto \\ Multidisciplinario de Biología Vegetal, Universidad Nacional de Córdoba - CONICET, Córdoba, Argentina
}

\begin{abstract}
Fire frequencies are currently increasing in many regions across the world as a result of anthropic activities, affecting ecological processes and plant population dynamics. Fire can generate important changes in soil properties, altering nutrient dynamics and thereby plant growth. Here we analyse fire frequency effects on soil quality and plant traits of three native perennial herbaceous plants (Cologania broussonetii, Desmodium uncinatum and Rhynchosia edulis; Fabaceae) with the capacity for biological $\mathrm{N}_{2}$ fixation that resprouts and are abundant after fire in Chaco Serrano forests. Based on 22-year fire history, we assessed plant traits in sites with low and high fire frequencies along with unburned scenarios. We found significantly lower water content, nitrates and electrical conductivity in frequently burned soils. As a result, the three species showed consistently lower leaf area and specific leaf area in both fire frequencies, implying lower growth rates in comparison to unburned sites. However, total leaf biomass was not affected by fire, leaf phosphorus concentration was higher in $R$. edulis in high fire frequency and leaf $\mathrm{N}$ concentration was twice as large in plants growing in sites of high fire frequency in C. broussonetii and R. edulis. Such an increase in $\mathrm{N}$ and phosphorus concentrations is likely a result of both their conservative use of resources and their biological $\mathrm{N}_{2}$ fixation capacity. To our knowledge, this is the first record of such contrasting fire effects observed consistently in three co-occurring species: while plant growth decreased with fire frequency, leaf nutritional traits remain unchanged or increased in frequently burned sites. Qualitydepleted and drier soils that result from increased fire frequencies may not only affect trait variation at the intraspecific level but can also drive to a homogenization of the plant community, selecting species with particular combinations of morphological and functional traits.
\end{abstract}

Key words: biological $\mathrm{N}_{2}$ fixation, fire regime, leaf nutrient, plant growth, specific leaf area.

\section{INTRODUCTION}

Fire is a natural and ubiquitous disturbance across terrestrial ecosystems shaping the distribution, structure and dynamics of biomes throughout the world (Bond et al. 2005). The impact of fire on plant communities, and their potential recovery, depends on both the historical fire regime (i.e. the frequency, intensity and seasonal patterns of fire over time) and the life history traits of the plant species adapted to that disturbance regime (Davies 2013). Anthropic activities such as land-use changes, global warming and human population growth can alter fire regimes, changing their frequency and/or intensity, and thus triggering potential irreversible consequences on ecological processes and plant population dynamics (Pausas \& Keeley 2009; Keeley et al. 2011). In the face of current fire regime changes, it is crucial to understand how vegetation responds to such increased fire frequency for predicting the consequences on vegetal communities around the world (Pausas et al. 2004).

${ }^{\star}$ Corresponding author.

Accepted for publication 11 February 2016.
Fire can generate important changes in soil properties in the short and long terms, affecting overall water and nutrient dynamics (Raison 1979). High fire frequencies increase water repellence affecting soil permeability, rendering soils less able to hold water. This is produced by the recurrent ash deposition that clogs soil pores, creating discreet and continuous water-repellent layers, which reduce hydraulic conductivity and water infiltration (Certini 2005). Simultaneously, the elimination of vegetation and litter layer increases the impact of raindrops and water runoff events, intensifying soil erosion (Certini 2005; González-Pelayo et al. 2015). In terms of chemical properties, fire induces organic matter mineralization; thus, organic carbon (C) and nitrogen $(\mathrm{N})$ are partly volatilized and lost to the atmosphere, while phosphorus $(\mathrm{P})$ can be either recycled by plants or lost by lixiviation. Part of the organic $\mathrm{N}$ also mineralizes to ammonium and nitrate $\left(\mathrm{NO}^{3-}\right)$ forms (Certini 2005). As reviewed by Wan et al. (2001), $\mathrm{NO}^{3-}$ levels initially tend to increase, reaching a maximum between 0.5 and 1 year following fire, but consistently decrease afterwards because of lixiviation and absorption by mineral and organic matter (Wan et al. 2001; Certini 2005). In summary, while increased soil nutrients are observed in the short term, high fire frequency in the long term significantly erodes soils 
depleting soil C and N, but not necessarily P (Certini 2005; Wang et al. 2012; Pellegrini et al. 2015).

Fire effects on soil properties can indirectly act as a selective agent on certain life history traits of plant species (e.g. Keeley et al. 2011). Several studies have evaluated the effects of fire on certain plant functional traits that are closely associated with photosynthesis and growth rates such as leaf area (LA), specific leaf area (SLA), leaf dry matter content (LDMC) as well as N and P leaf concentrations (Paula \& Pausas 2006; Anacker et al. 2011; Cianciaruso et al. 2012; Dantas et al. 2013a). Particularly, SLA has been considered a key functional trait because it is an indicator of broad resource-use strategies and ecosystem functioning (Díaz et al. 1998; Anacker et al. 2011). As a resourceacquisition trait, it is modulated by climate, disturbance (including fire) and biotic interactions (Anacker et al. 2011). For example, in areas with soil nutrient limitations caused by fire, plants may show slower growth resulting in lower SLA values (Anacker et al. 2011). Thus, by assessing changes in SLA across contrasting fire frequency conditions in relatively abundant plant species, we may anticipate potential changes in important ecosystem processes such as litter decomposition, productivity or flammability (Díaz et al. 1999; Anacker et al. 2011).

Most research up to now has focused on assessing interspecific plant functional trait responses under natural abiotic environmental variability (e.g. Rosbakh et al. 2015) or disturbances (e.g. Díaz et al. 1999), including fire (Pausas et al. 2004; Saura-Mas \& Lloret 2009) to characterize plant communities. Only a handful of studies have assessed the intraspecific variability of plant functional traits associated with either natural (e.g. Albert et al. 2010; Rosbakh et al. 2015) or anthropogenic disturbance regimes (e.g. Prado-Júnior et al. 2015). The few studies assessing fire frequency effects on plant functional traits have found decreased SLA and plant nutrient levels with increased fire frequency (Loiola et al. 2010; Cianciaruso et al. 2012; Dantas et al. 2013a). Increased fire frequency may have an important influence on intraspecific variability at the local scale, affecting nutritional niche breadth of species and system stability (Cianciaruso et al. 2012; Moreira et al. 2012; Carbone et al. 2013; Dantas et al. 2013a). However, because not all plants respond equally to nutritionally stressed environments, studies assessing intraspecific variability in plant functional traits may allow the detection of species-specific responses that otherwise may not be apparent in community-level studies. For example, plant species with the capability of biological $\mathrm{N}_{2}$ fixation may counterbalance nutrient limitations, especially nitrogen, imposed by high fire frequencies. Species with biological $\mathrm{N}_{2}$ fixation can play an important role in microenvironmental nutrient cycling dynamics in post-fire ecosystems (Carreira \& Niell 1992; Goergen \& Chambers 2009).

Native plant communities of Chaco Serrano forest in central Argentina are currently under different levels of exploitation, which are increasingly reducing their diversity (Cabido et al. 2010). In the past decades, the fire regime in this region has been modified by anthropogenic activities and climatic conditions (Bravo et al. 2010). Although humans are responsible for most ignitions, climatic variables, such as annual precipitation, annual potential evapotranspiration and temperature seasonality, are also important drivers of fire frequency (Argañaraz et al. 2015a). A recent study conducted in central Argentina showed that Sierras Chicas was the area most affected by fire, with the highest number of fire events, burned area and fire frequency over the 1999-2011 period (Argañaraz et al. 2015b).

Post-fire floristic assessments of Sierras Chicas region have revealed that several native Fabaceae are an important component of post-fire resprouting and also are used as foraging resources for cattle (Fuentes et al. 2011; Carbone 2015). Among the herbaceous species with the highest relative frequency in the community are the $\mathrm{N}_{2}$-fixing perennials Cologania broussonetii (Balb.) DC., Desmodium uncinatum (Jacq.) DC., and Rhynchosia edulis Griseb. As many long-lived resprouters, they have a conservative use of resources (Saura-Mas \& Lloret 2009). These species not only are present in sites with frequent fires, but they are also the most abundant herbaceous Fabaceae of Chaco Serrano forest (Giorgis et al. 2011). Analyzing the intraspecific variability of plant functional traits of these native herbaceous species in frequently burned environments is a crucial first step for understanding their responses to fire.

In this paper, we analyse the effects of fire frequency on soil properties and on intraspecific variability of plant functional traits of C.broussonetii, D. uncinatum and $R$. edulis, native perennial $\mathrm{N}_{2}$-fixing herbaceous plant species abundant in post-fire resprouting of Chaco Serrano forest. We hypothesize that increased fire frequency decreases soil moisture and overall soil fertility, which in turn affects intraspecific plant functional traits such as LA, SLA, LDMC and biomass (Fig. 1). Thus, decreased soil quality induced by frequent fires will positively correlate with decreased intraspecific plant functional traits (except for LDMC; Fig. 1). However, because the species have biological $\mathrm{N}_{2}$ fixation capacity and an efficient and conservative use of resources, leaf nutrients ( $\mathrm{N}$ and $\mathrm{P}$ ) would not be affected by lowernutrient soils in frequently burned scenarios. Finally, because the species share ecological and life-history traits, the overall effects of fire frequency on plant traits at the interspecific level will be similar.

\section{METHODS}

\section{Study area}

The study was conducted in the eastern hillsides of Sierras Chicas of Córdoba, Argentina. The study area corresponds to 


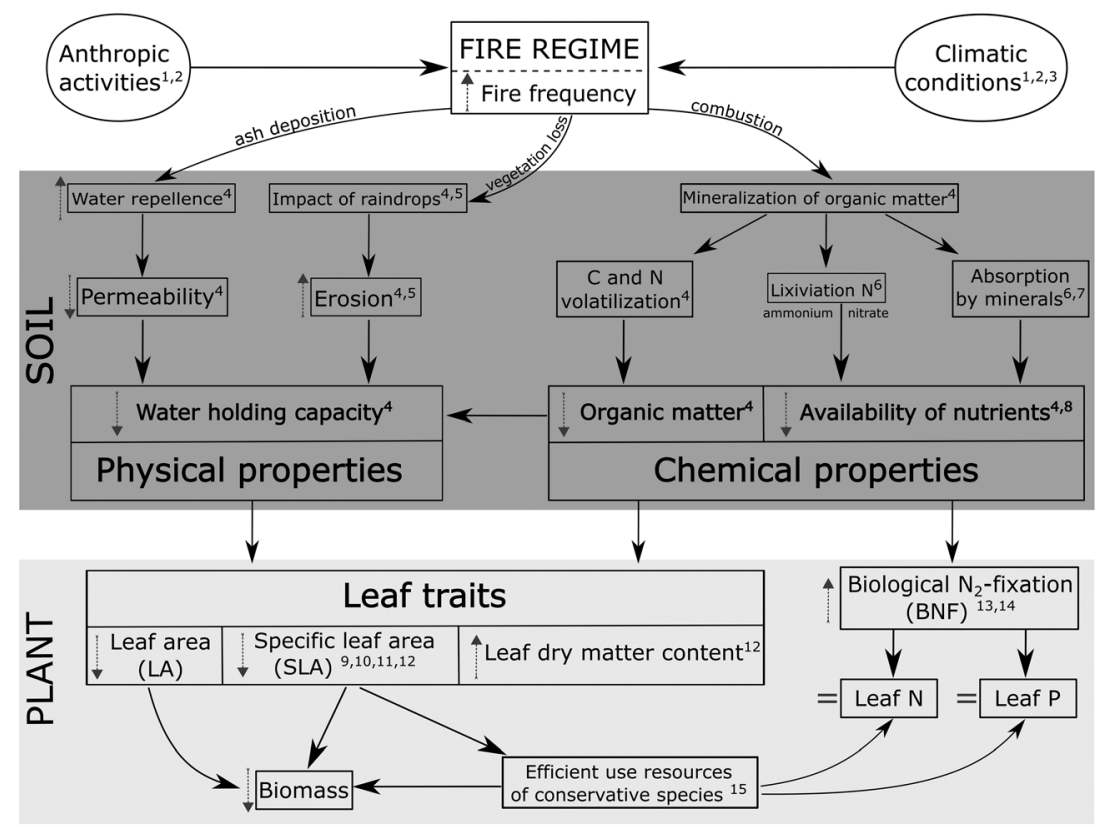

Fig. 1. Diagram of the hypothesized response mechanisms of fire frequency on soil characteristics and plant traits. Increased fire frequency decreases overall soil fertility (physical and chemical properties), which in turn affects morphological leaf traits (leaf area (LA), specific leaf area (SLA) and leaf dry matter content (LDMC)) but not nutritional leaf traits (nitrogen (N) and phosphorus (P)) because of two compensatory ecological mechanisms: biological $\mathrm{N}_{2}$ fixation and conservative use of resources of the studied Fabaceae species. Superscript numbers indicate the references that support the predictions: (1) Argañaraz et al. (2015a), (2) Argañaraz et al. (2015b), (3) Bravo et al. (2010), (4) Certini (2005), (5) González-Pelayo et al. (2015), (6) Wang et al. (2012), (7) Wan et al. (2001), (8) Pellegrini et al. (2015), (9) Anacker et al. (2011), (10) Loiola et al. (2010), (11) Cianciaruso et al. (2012), (12) Dantas et al. (2013a), (13) Carreira \& Niell (1992), (14) Goergen and Chambers (2009) and (15) Saura-Mas and Lloret (2009).

the Chaco phytogeographical province, Chaco Serrano district (Cabrera 1971). The predominant vegetation is a xerophytic subtropical forest, characterized by closed and open forests depending on grazing pressures and fire recurrence (Luti et al. 1979) with tree layer (8-15 $\mathrm{m}$ high) dominated by Aspidosperma quebracho-blanco Schltdl., Prosopis spp., Zanthoxylum coco Engl. and Lithraea molleoides (Vell.) Engl. (Luti et al. 1979). Elevation ranges from 400 to $1300 \mathrm{~m}$ a.s. 1. and the climate is characterized as a warm continental type with the average minimum and maximum temperatures ranging between $-10^{\circ} \mathrm{C}$ and $26^{\circ} \mathrm{C}$. Precipitation ranges between 500 and $1200 \mathrm{~mm}$ per year (Cabrera 1971), with an annual average of $881 \mathrm{~mm}$ for the 1990-2012 period within the study sites (Malanca Family, personal communication). Rain concentrates in the warm season, between October and March, delimiting a clear period of water deficit during autumn and winter. Wildfires typically coincide with the end of the dry season, and when temperatures begin to increase, fuel moisture is low and winds reach their maximum speeds (Bravo et al. 2001). In the last 30 years there has been a documented increase in wildfire frequency for the Chaco region, mainly associated with an increase of rains at a regional level, causing a greater accumulation of fine flashy (i.e. high surface area-to-volume) fuels (Miglietta 1994; Bravo et al. 2010). Wildfires in the Chaco Serrano forest are currently mainly caused by humans as a result of accidental or negligent ignitions. Within Sierras Chicas, the fire frequency over the period of 1999-2011 was estimated in one fire every 5 years (Argañaraz et al. 2015b).

\section{Study species}

Cologania broussonetii (Balb.) DC., D. uncinatum (Jacq.) DC. and R. edulis Griseb. (Fabaceae, Faboideae) are subtropical native perennial herbs widely distributed from southern United States to central Argentina. These species are a main component of the herbaceous stratum of Chaco Serrano forests (Giorgis et al. 2011); thus, their relative abundance is similar across all study sites, ranging from 2.5 to $7.5 \%$ total cover (Carbone 2015). They represent important foraging resources for native and livestock grazing animals in tropical dry forests (Fortunato 1983; Vanni 2001). Their growing season begins in late spring and lasts throughout the summer, with individuals growing branches from 0.5 to $2.5 \mathrm{~m}$ long. In winter, they undergo a period of dormancy that matches with the dry season where they lose their aerial biomass. The three species have root nodules as corroborated in field observations, with the capacity of biological $\mathrm{N}_{2}$ fixation. Their underground reserve organs are woody rhizomes and xylopodial roots that can reach 2 to $5 \mathrm{~cm}$ in diameter and represent a post-fire regeneration strategy allowing them to survive fire and resprout quickly (personal observations). 


\section{Site selection}

There is a common problem in most fire studies, which implies that rarely all aspects of fire regimes are considered or controlled (Whelan 1995). While acknowledging such limitation, here, we searched for sites sharing fire frequency and the same time elapsed since the last fire. To accomplish this, we compiled the fire history of the last 22 years from the entire study area using different databases. We used fire records registered by M.A. Giorgis together with Civil Defence of Rio Ceballos city for the period of 1991-2011 (Giorgis et al. 2013). We further corroborated the geographic boundaries of the fire events from vectors of fire in coordinates based on Landsat TN and ETM (30 m spatial resolution) satellite imagery for the 1999-2011 period (Argañaraz et al. 2015a). Finally, we conducted interviews with local area residents combined with in situ observations for final corroboration of fire records. We selected nine sites with different fire regime history in the last 22 years: (i) three ' $u n$ burned' sites; (ii) three 'low fire frequency' sites (1-2 fires); and (iii) three 'high fire frequency' sites (3-4 fires) (Table 1; Fig. 2). The sites were georeferenced; the elevation and orientation were obtained from a GPS. At each site, we estimated the stocking rate by counting cattle faeces in an area of $500 \mathrm{~m}^{2}$. The stocking rates were low and similar among all study sites. The average distance between sites was $1530 \mathrm{~m}$.

\section{Soil properties}

In December 2013, we collected four soil samples $(0-10 \mathrm{~cm}$ depth) taken randomly nearby the studied individuals at each of the nine study sites. The samples were immediately placed in double plastic bags and stored in a portable Styrofoam cooler to avoid soil dehydration in the field. To obtain gravimetric soil moisture, the samples were weighed immediately after collection and placed in a drying oven at $60^{\circ} \mathrm{C}$ until the sample reached a constant weight. Soil water content (\%) was calculated as the ratio between water weight (g) and dry soil weight (g). Subsequently, we made a single composite sample from the four samples per site, and took them to the Soil and Water Laboratory of the Faculty of Agronomic Sciences, National University of Córdoba. The soil parameters analysed were (i) organic matter (OM, \%); (ii) organic C (\%); (iii) total N (\%); (iv) $\mathrm{C}: \mathrm{N}$ ratio; (v) $\mathrm{NO}^{3-}$ (ppm); (vi) extractable $\mathrm{P}$ (ppm); (vii) sulphates $\left(\mathrm{SO}_{4}{ }^{2-}, \mathrm{ppm}\right)$; (viii) current $\mathrm{pH}$; and (ix) electric conductivity (EC, dS/m). The analyses were carried out according to (i) organic $\mathrm{C}$ by the Walkley-Black wet digestion method; (ii) total $\mathrm{N}$ by semi-micro Kjeldahl; (iii) $\mathrm{NO}^{3-}$ using ion selective electrodes; (iv) extractable $\mathrm{P}$ by the Bray-Kurtz method; (v) $\mathrm{pH}$ in water; and (vi) electrical conductivity (EC; $1: 1$, soil: water ratio). Soil organic carbon data were multiplied by a factor of 1.72 to give soil OM values (Howard \& Howard 1990). The soil texture in the study area was characterized as a sandy loam.

\section{Sampling and measurements}

The sampling of individuals was also conducted in December 2013. Twelve adult individuals randomly selected from each of the three species in nine sites belonging to three fire scenarios (36 individuals/species/scenario; totalling 108 individuals

Table 1. Topographic characteristics and fire regime (1991-2013 period) of the nine studied sites in three different fire scenarios of Chaco Serrano, Córdoba, Argentina

\begin{tabular}{|c|c|c|c|c|c|c|c|}
\hline $\begin{array}{l}\text { Map } \\
\text { code }\end{array}$ & $\begin{array}{l}\text { Name } \\
\text { of site }\end{array}$ & $\begin{array}{c}\text { Range of } \\
\text { elevation (m) }\end{array}$ & Coordinates & $\begin{array}{c}\text { Dominant } \\
\text { slope aspect }\end{array}$ & $\begin{array}{l}\text { Wildfire } \\
\text { years }\end{array}$ & $\begin{array}{l}\text { Number of } \\
\text { wildfires }\end{array}$ & Fire scenario \\
\hline 1 & La Quebrada & $824-845$ & $31^{\circ} 9^{\prime} 11.73^{\prime \prime S} 64^{\circ} 20^{\prime} 40.35^{\prime \prime W}$ & W & - & 0 & Unburned \\
\hline 2 & Indarte & $976-1000$ & $31^{\circ} 6^{\prime} 38.83^{\prime \prime S} 64^{\circ} 22^{\prime} 18.54^{\prime \prime W}$ & Irregular & - & 0 & \\
\hline 3 & Salto & $952-965$ & $31^{\circ} 6^{\prime} 29.48^{\prime \prime S} 64^{\circ} 21^{\prime} 22.38^{\prime \prime W}$ & $\mathrm{NE}$ & - & 0 & \\
\hline 4 & Escuela & $980-1000$ & $31^{\circ} 6^{\prime} 52.45^{\prime \prime S} 64^{\circ} 21^{\prime} 54.10^{\prime \prime W}$ & NW & 2011 & 1 & Low fire frequency \\
\hline 5 & Site I & $1132-1180$ & $31^{\circ} 7^{\prime} 27.30^{\prime \prime S} 64^{\circ} 22^{\prime} 43.33^{\prime \prime W}$ & $\mathrm{E}$ & $\begin{array}{l}1995 \\
2010\end{array}$ & 2 & \\
\hline 6 & Malanca & $1011-1040$ & $31^{\circ} 6^{\prime} 23.70^{\prime \prime S} 64^{\circ} 23^{\prime} 0.51^{\prime \prime W}$ & $\mathrm{NE}$ & $\begin{array}{l}2003 \\
2011\end{array}$ & 2 & \\
\hline 7 & Site F & $1017-1036$ & $31^{\circ} 7^{\prime} 8.16^{\prime \prime S} 64^{\circ} 21^{\prime} 48.50^{\prime \prime W}$ & Irregular & $\begin{array}{l}1995 \\
2007 \\
2011\end{array}$ & 3 & High fire frequency \\
\hline 8 & Site A & $1180-1206$ & $31^{\circ} 7^{\prime} 49.94^{\prime \prime S} 64^{\circ} 24^{\prime} 10.49^{\prime \prime W}$ & $\mathrm{~N}$ & $\begin{array}{l}1991 \\
1993 \\
2000 \\
2011\end{array}$ & 4 & \\
\hline 9 & Candonga & $1030-1040$ & $31^{\circ} 5^{\prime} 38.53^{\prime \prime S} 64^{\circ} 21^{\prime} 5.79^{\prime \prime W}$ & $\mathrm{~N}$ & $\begin{array}{l}1995 \\
2003 \\
2008 \\
2011\end{array}$ & 4 & \\
\hline
\end{tabular}




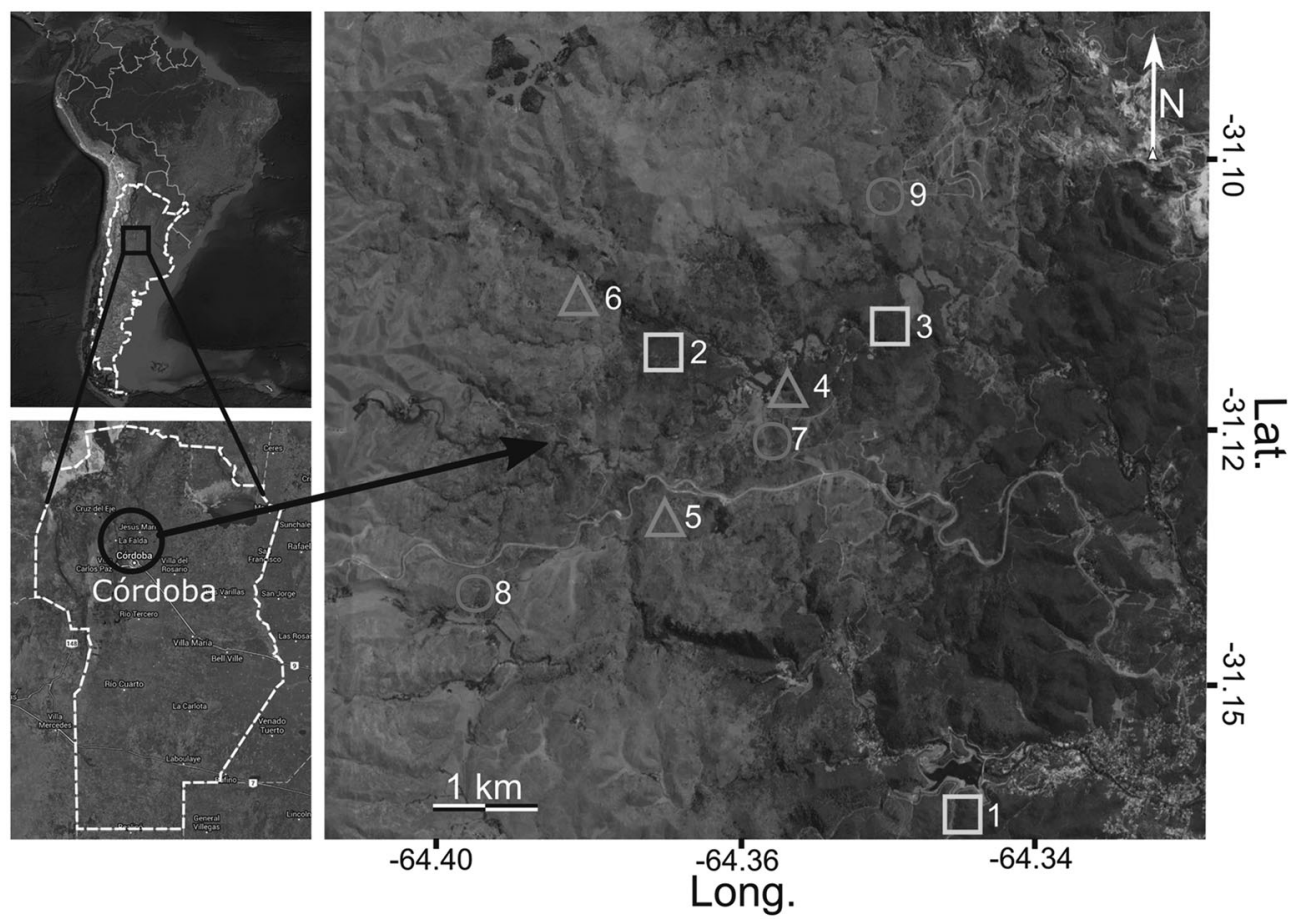

Fig. 2. Location of study sites in the Chaco Serrano forest (Córdoba province) of Central Argentina. Fire frequency scenarios: unburned (sites 1, 2 and 3; squares), low fire frequency (sites 4, 5 and 6; triangle) and high fire frequency (sites 7, 8 and 9; circle).

per species) were marked with aluminium tags. All sampled individuals from each species were in reproductive stage at the time of sampling and were similar in size, and thereby of approximately similar total plant age. The voucher specimens were deposited in ACOR herbarium of the Faculty of Agronomic Sciences, National University of Córdoba. The studied individuals at each site were separated from each other by a minimal distance of $3 \mathrm{~m}$. In each individual, we randomly selected five fully expanded green leaves of similar age (discarding the base and tip leaves of the branches) concurrently in all sites and performed the following measurements: (i) we measured the leaf area $\left(\mathrm{LA}, \mathrm{cm}^{2}\right.$ ) by scanning the fresh leaves and then using Image $1.47 \mathrm{v}$ software (National Institutes of Health, USA); (ii) we measured the SLA $\left(\mathrm{cm}^{2} / \mathrm{g}\right)$ by dividing leaf area and leaf dry mass; (iii) we measured the LDMC (mg/g) by dividing leaf dry mass and its saturated fresh leaf mass (for the measurements of LA, SLA and LDMC, we followed the protocols detailed by Pérez-Harguindeguy et al. 2013); (iv) we estimated the total leaf biomass (TLB; g) per individual by multiplying the total number of leaves and leaf dry mass; and (v) we obtained leaf total $\mathrm{N}$ and (vi) P concentration ( $\mathrm{mg} / \mathrm{g}$ ) from the same randomly selected fully expanded normal green leaves of similar age leaves previously mentioned of five individuals from each species per site ( $N=45$ individuals per species). These leaves were ground and then digested in a $\mathrm{CuSO}_{4} / \mathrm{K}_{2} \mathrm{SO}_{4} / \mathrm{H}_{2} \mathrm{SO}_{4}$ solution for $30 \mathrm{~min}$ at $160^{\circ} \mathrm{C}$, and then $1 \mathrm{~h}$ at $380^{\circ} \mathrm{C}$ in a Easy Block Smart Digester (Westco). After digestion, we proceeded to measure the total concentration of $\mathrm{N}$ and $\mathrm{P}$ with an automated spectrophotometer SmartChem 200 (Westco).

\section{Data analysis}

Analyses were performed in R (R Core Team 2015) and were conducted separately for each plant species. We used linear mixed-effect models (lme function from the nlme package; Pinheiro et al. 2009) for the quantitative response variables (LA, SLA, LDMC, TLB, N and P) and generalized the linear mixed-effect models (glmer function from the lme4 package; Bates et al. 2014) for soil water content, due to its binomial error distribution. We used fire frequency as the main fixed effect with three levels (unburned, low fire frequency and high fire frequency), and site as a random factor $(N=9)$ nested within fire frequency scenario. The significance of fixed effect was assessed with $F$-statistics in linear mixed-effect models and with Wald-Z in generalized linear mixed-effect models. For soil properties (except soil water content), which were obtained at the site level, we tested for differences between the three fire frequency scenarios using generalized linear models ( $\mathrm{glm}$ function from the stats package) for variables with binomial error distribution $(\mathrm{OM}, \mathrm{C}$ and $\mathrm{N}$ ) and with $F$-statistics for the rest of the variables that had normal error distribution. Model parameters were estimated with restricted maximum likelihood and maximum likelihood methods for lme and glme functions respectively. For each species, we tested for relationships between soil properties and leaf traits across all sites with Pearson correlation 
coefficients. Finally, we assessed the interspecific response patterns among the species for the three most relevant plant traits SLA, leaf $\mathrm{N}$ and leaf P. Because the same response variables had quite different magnitudes and ranges of variation among the species, we calculated a new standardized measure (i.e. effect size) for each plant functional trait and used a metaanalytical approach to compare their responses across species (Koricheva et al. 2013). For these analyses we only considered response variables in two contrasting conditions (burned and unburned) and used the unbiased standardized mean difference (Hedges's $d$ ) between burned and unburned conditions as the effect size. Thus, we pooled data from high and low fire frequencies and used it as the treatment effect (refer to Koricheva et al. 2013 for calculation details). The effect size $d$ can be interpreted as the inverse-variance-weighted difference in plant functional trait values between unburned and burned conditions, measured in units of standard deviation. Negative values of $d$ imply a decrease in the mean value of the trait in burned conditions, whereas a positive $d$ value corresponds to an increase as compared to the unburned conditions.

\section{RESULTS}

\section{Soil properties}

We found significant differences in water content, $\mathrm{NO}^{3-}$ and EC among fire frequency scenarios, with consistently higher values of these three soil parameters in the unburned conditions (Table 2). Soil water content was similar in both low and high fire frequencies. Soil $\mathrm{NO}^{3-}$ levels differed only between the unburned and high fire frequency scenarios. Soil EC differed significantly among the three conditions (Table 2). While the rest of the soil parameters showed consistently higher values in the unburned sites, no statistical significant differences were detected among the three fire frequency conditions. Because water content, $\mathrm{NO}^{3-}$ and EC were highly correlated among themselves (Pearson's $r$ 0.72-0.88; $P<0.0001)$, we calculated a new integrated soil quality variable by multiplying these three significant soil variables (refer to AguirreAcosta et al. 2014). We then used this integrated soil quality variable (log-transformed) to run correlations with leaf traits.

\section{Intraspecific variability in leaf traits}

Leaf area and SLA showed consistently the same response pattern in each of the three species. Leaf area and SLA significantly decreased in low and high fire frequency scenarios in comparison to unburned conditions (Table 3; Fig. 3a-f). In contrast, LDMC showed consistent increases in sites of low and high fire frequencies compared to unburned conditions. These differences were significant only for C.broussonetii (Table 3). Site effect (random factor) explained less than 35\% of model variance in all response variables in the three species.

\section{Intraspecific variability in leaf nutrients and TLB}

A higher leaf $\mathrm{N}$ concentration was observed in $C$. broussonetii and $R$.edulis in the high fire frequency scenarios, doubling the levels of the unburned scenarios (Table 3; Fig. 3g, h). In contrast, $\mathrm{N}$ values in D. uncinatum were similar across all fire conditions. The leaf $\mathrm{P}$ concentration in R.edulis differed significantly between the unburned and the high fire frequency scenarios, with higher $\mathrm{P}$ levels in the latter (Table 3; Fig. 3i). In both C.broussonetii and D. uncinatum, the $\mathrm{P}$ concentrations were similar among fire scenarios. The estimated TLB values showed non-significant differences among fire frequencies in any of the three species. However, the highest TLB average value in each of the three species coincided with either low or high fire frequency scenarios (Table 3). In all these analyses, site identity always explained less than $35 \%$ of the variation in response variables in each species.

\section{Intraspecific relationship between soil quality and leaf traits}

In general, the integrated soil quality variable was positive and strongly correlated with LA and SLA for each of the three studied species $(r=0.6-0.87 ; P<0.05)$. Additionally, we observed that sites with highest soil fertility and leaf trait values were consistently found in unburned conditions (Fig. 4a, b). Leaf dry matter content was negatively correlated with soil quality in the three plant species, but it was significant only for C.broussonetii $(r=-0.86 ; P=0.005$; Fig. $4 \mathrm{c})$. Leaf $\mathrm{N}$ was not related to soil quality in C.broussonetii and D. uncinatum but it was negatively related to soil quality in $R$.edulis $(r=-0.93 ; P=0.0007$; Fig. $4 d)$. Leaf $P$ was not related with soil quality in any of the three studied species $(P>0.05)$ (Fig. 4e).

\section{Interspecific response patterns in SLA and leaf nutrients}

At the interspecific level, SLA was consistently lower in burned conditions for the three studied species (i.e. confidence intervals did not overlap Hedges's $d$ cero value). In contrast, leaf $\mathrm{N}$ and $\mathrm{P}$ significantly increased in burned scenarios, with the exception of D. uncinatum (Fig. 5a) that showed no changes in leaf nutrients (i.e. confidence intervals overlap Hedges's $d$ cero value). The overall response of SLA to fire across the species was negative and significantly different from cero (Fig. 5b), implying a net decrease in SLA in burned conditions. Leaf $\mathrm{N}$ was on average significantly higher 
Table 2. Soil properties of the three different fire frequency scenarios

\begin{tabular}{lcccc}
\hline Soil property & Unburned & Low fire frequency & High fire frequency & Statistical tests \\
\hline Water content (\%) & $11.05 \pm 4.90 \mathbf{a}$ & $3.36 \pm 2.20 \mathbf{b}$ & $3.18 \pm 1.20 \mathbf{b}$ & $Z>2.446 ; P<0.014$ \\
Organic matter (\%) & $6.37 \pm 0.25$ & $5.23 \pm 1.77$ & $5.00 \pm 0.70$ & $Z<0.721 ; P>0.471$ \\
Organic carbon (\%) & $3.70 \pm 0.20$ & $3.03 \pm 1.08$ & $2.90 \pm 0.36$ & $Z<0.547 ; P>0.584$ \\
Total nitrogen (\%) & $0.27 \pm 0.01$ & $0.24 \pm 0.07$ & $0.21 \pm 0.05$ & $Z<0.153 ; P>0.879$ \\
C:N ratio & $13.90 \pm 1.41$ & $12.60 \pm 1.03$ & $13.80 \pm 1.21$ & $F=0.989 ; P=0.425$ \\
Nitrates (ppm) & $38.27 \pm 19.10 \mathbf{a}$ & $21.70 \pm 6.68 \mathbf{a b}$ & $8.40 \pm 2.46 \mathbf{b}$ & $F=4.829 ; P=0.050$ \\
Phosphorous (ppm) & $6.10 \pm 0.50$ & $3.87 \pm 2.70$ & $4.17 \pm 0.90$ & $F=1.611 ; P=0.275$ \\
Sulphates (ppm) & $24.07 \pm 15.40$ & $23.63 \pm 5.83$ & $22.23 \pm 9.21$ & $F=0.023 ; P=0.977$ \\
pH & $6.50 \pm 0.30$ & $6.17 \pm 0.70$ & $6.30 \pm 0.20$ & $F=0.442 ; P=0.662$ \\
Electric conductivity (dS/m) & $0.67 \pm 0.10 \mathbf{a}$ & $0.5 \pm 0.00 \mathbf{b}$ & $0.37 \pm 0.10 \mathbf{c}$ & $F=30.500 ; P=0.0007$ \\
\end{tabular}

Values are means \pm SD. Different letters in bold indicate statistical significant differences $(P<0.05)$ in parameter value among fire frequency scenarios.

Table 3. Functional traits of three native perennial plant species in three different fire frequency scenarios

\begin{tabular}{llcccc}
\hline Species & \multicolumn{1}{c}{ Trait } & Unburned & Low fire frequency & High fire frequency & Statistical tests \\
\hline Cologania broussonetii & $\mathrm{LA}\left(\mathrm{cm}^{2}\right)$ & $29.08 \pm 7.09 \mathbf{a}$ & $10.97 \pm 3.80 \mathbf{b}$ & $11.99 \pm 3.08 \mathbf{b}$ & $F=63.294 ; P=0.0001$ \\
& $\mathrm{SLA}\left(\mathrm{cm}^{2} / \mathrm{g}\right)$ & $294.85 \pm 70.07 \mathbf{a}$ & $182.05 \pm 22.51 \mathbf{b}$ & $182.48 \pm 33.81 \mathbf{b}$ & $F=13.088 ; P=0.007$ \\
& $\mathrm{LDMC}(\mathrm{mg} / \mathrm{g})$ & $263.12 \pm 24.02 \mathbf{a}$ & $305.44 \pm 33.92 \mathbf{a b}$ & $316.76 \pm 39.06 \mathbf{b}$ & $F=4.954 ; P=0.027$ \\
& $\mathrm{TLB}(\mathrm{g})$ & $1.72 \pm 0.81$ & $1.46 \pm 0.93$ & $2.25 \pm 2.02$ & $F=0.554 P=0.602$ \\
& $\mathrm{~N}(\mathrm{mg} / \mathrm{g})$ & $4.03 \pm 3.80 \mathbf{a}$ & $8.01 \pm 2.60 \mathbf{a b}$ & $8.88 \pm 2.24 \mathbf{b}$ & $Z=4.457 ; P=0.035$ \\
& $\mathrm{P}(\mathrm{mg} / \mathrm{g})$ & $1.86 \pm 1.34$ & $2.58 \pm 0.90$ & $2.25 \pm 0.72$ & $F=0.808 ; P=0.489$ \\
Desmodium uncinatum & $\mathrm{LA}\left(\mathrm{cm}^{2}\right)$ & $31.99 \pm 7.68 \mathbf{a}$ & $20.26 \pm 6.84 \mathbf{b}$ & $21.17 \pm 6.90 \mathbf{b}$ & $F=9.528 ; P=0.014$ \\
& $\mathrm{SLA}\left(\mathrm{cm}^{2} / \mathrm{g}\right)$ & $320.21 \pm 78.47 \mathbf{a}$ & $210.40 \pm 32.00 \mathbf{b}$ & $214.03 \pm 31.16 \mathbf{b}$ & $F=25.234 ; P=0.001$ \\
& $\mathrm{LDMC}(\mathrm{mg} / \mathrm{g})$ & $276.41 \pm 27.47$ & $304.71 \pm 22.07$ & $307.41 \pm 23.30$ & $F=3.150 ; P>0.116$ \\
& $\mathrm{TLB}(\mathrm{g})$ & $2.26 \pm 1.65$ & $3.13 \pm 2.07$ & $3.64 \pm 2.09$ & $F=0.863 P=0.468$ \\
& $\mathrm{~N}(\mathrm{mg} / \mathrm{g})$ & $8.36 \pm 2.23$ & $8.68 \pm 2.64$ & $8.18 \pm 2.97$ & $F=0.232 ; P=0.800$ \\
& $\mathrm{P}(\mathrm{mg} / \mathrm{g})$ & $2.21 \pm 1.03$ & $1.80 \pm 0.67$ & $1.62 \pm 0.51$ & $F=0.986 ; P=0.426$ \\
& $\mathrm{LA}\left(\mathrm{cm}^{2}\right)$ & $33.11 \pm 9.05 \mathbf{a}$ & $14.98 \pm 4.06 \mathbf{b}$ & $13.44 \pm 3.65 \mathbf{b}$ & $F=56.186 ; P=0.0001$ \\
Rhynchosia edulis & $\mathrm{SLA}\left(\mathrm{cm}^{2} / \mathrm{g}\right)$ & $259.59 \pm 70.19 \mathbf{a}$ & $170.71 \pm 19.27 \mathbf{b}$ & $174.07 \pm 34.77 \mathbf{b}$ & $F=9.776 ; P=0.013$ \\
& $\mathrm{LDMC}(\mathrm{mg} / \mathrm{g})$ & $354.81 \pm 29.15$ & $371.31 \pm 26.94$ & $370.60 \pm 38.75$ & $F=1.167 ; P=0.373$ \\
& $\mathrm{TLB}(\mathrm{g})$ & $2.84 \pm 1.95$ & $3.90 \pm 3.16$ & $3.11 \pm 2.41$ & $F=0.311 ; P=0.744$ \\
& $\mathrm{~N}(\mathrm{mg} / \mathrm{g})$ & $2.40 \pm 1.45 \mathbf{a}$ & $3.26 \pm 1.49 \mathbf{a}$ & $4.77 \pm 1.20 \mathbf{b}$ & $F=11.326 ; P=0.009$ \\
& $\mathrm{P}(\mathrm{mg} / \mathrm{g})$ & $0.78 \pm 0.32 \mathbf{a}$ & $0.95 \pm 0.19 \mathbf{a b}$ & $1.18 \pm 0.34 \mathbf{b}$ & $F=3.307 ; P=0.043$ \\
\hline
\end{tabular}

Values are means \pm SD. Different letters in bold in each column indicate statistical significant differences $(P<0.05)$ in parameter values among fire frequency scenarios determined by linear mixed-effect models with fire frequency as fixed effect and site as random factor.

LA, leaf area; LDMC, leaf dry matter content; N, leaf total nitrogen concentration; P, leaf total phosphorous concentration; SLA, specific leaf area; TLB, total leaf biomass.

in burned conditions, and leaf P did not significantly change in burned and unburned conditions across all species, as observed by the overlapping confidence intervals with cero (Fig. 5b).

\section{DISCUSSION}

The role of fire as modulator of environmental filters is fundamental in structuring and generating plant community and population traits' variability (Dantas et al. 2013a, 2013b; Ojeda et al. 2010). Natural fire regimes, which involve fire frequency, intensity and time since last fire, can be altered by human activities and seriously affect biodiversity (Keeley et al. 2011). Measuring all of such fire regime aspects simultaneously is seldom achieved in a single study, which is a generalized shortcoming of most fire studies (Whelan 1995). Here we confirmed our initial hypotheses and found that increased fire frequency caused a strong decrease in certain fundamental soil quality parameters, which in turn drastically modified intraspecific leaf functional traits. However, we observed contrasting effects in morphological versus nutritional traits within the same plant species. While LA and SLA decreased, TLB, N, and P were not affected or increased with fire frequency in these three 
(a)

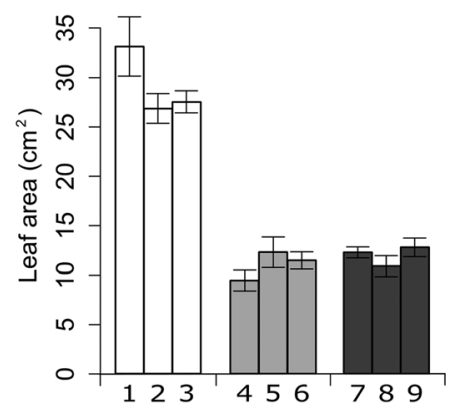

(d)

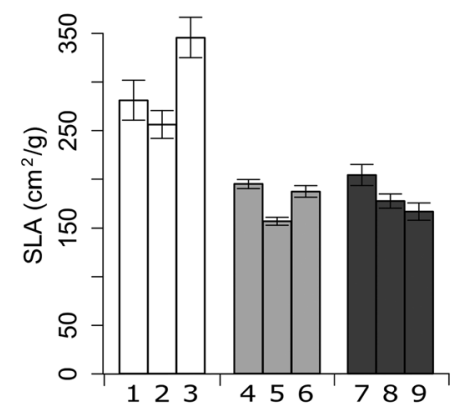

(g) Cologania broussonetii

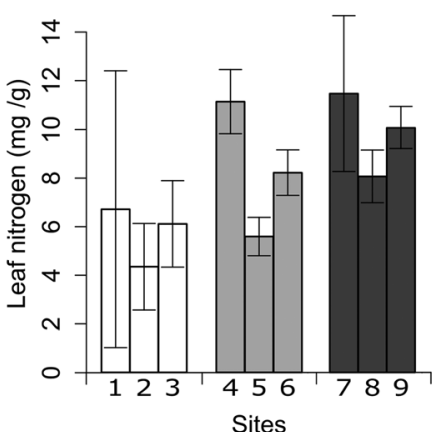

(b) Desmodium uncinatum

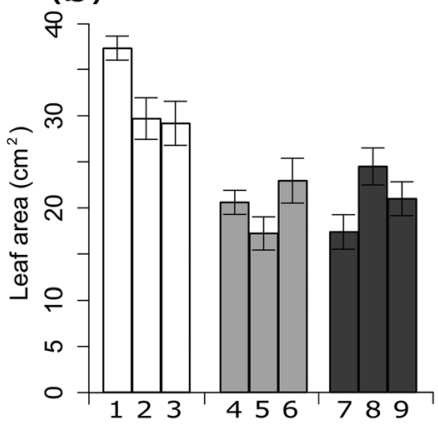

(e) Desmodium uncinatum
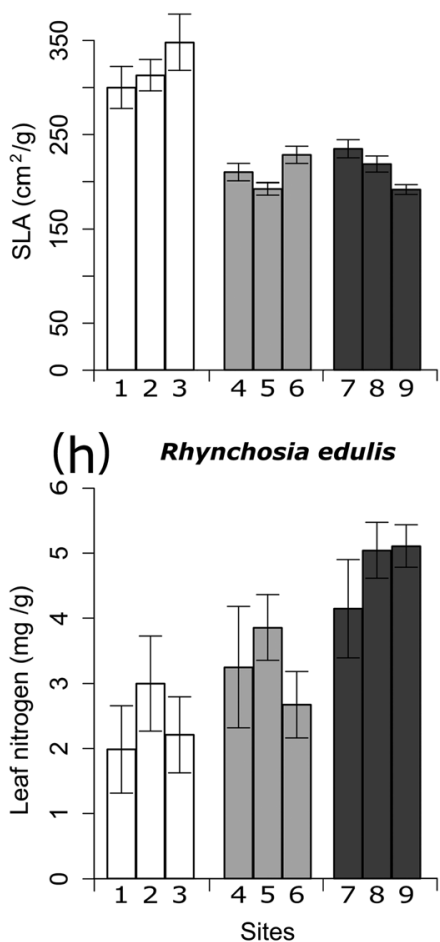

(C) Rhynchosia edulis

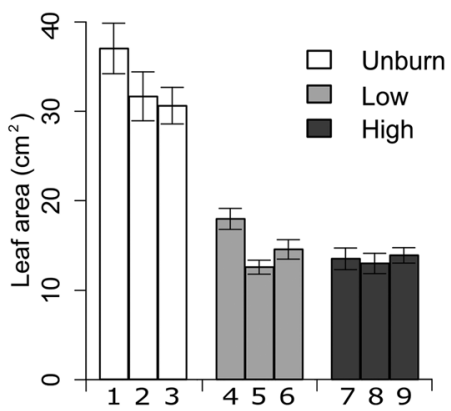

(f) Rhynchosia edulis

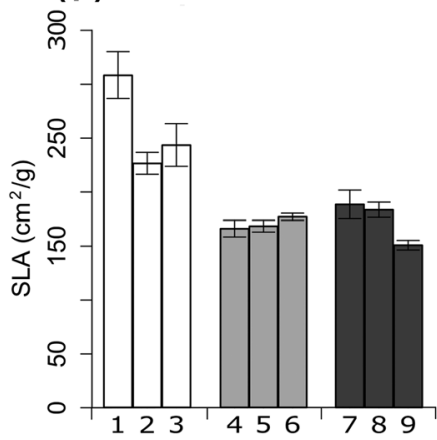

(i) Rhynchosia edulis

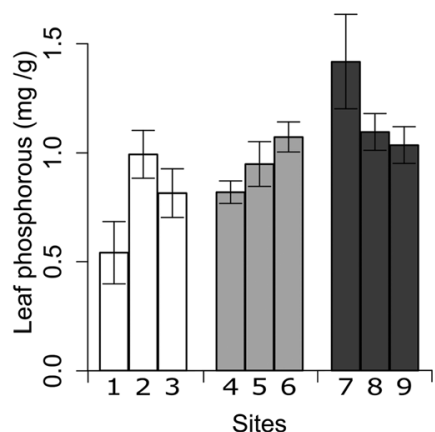

Fig. 3. Leaf area (a, b, c), specific leaf area (SLA; d, e, f), leaf nitrogen (N; g, h) and phosphorous (P; i) of three native plant species in nine sites with three different fire regimes: unburned (white bars), low fire frequency (light grey bars) and high fire frequency (dark grey bars). Values are means \pm standard error.

species. At the interspecific level, as a consequence of sharing ecological and life-history traits, the overall response of the three species was similar.

High fire recurrence enhances soil hydrophobicity affecting water infiltration into soil and increasing runoff events (Certini 2005; González-Pelayo et al. 2015), which leads to soil erosion and overall lower soil moisture (Shakesby \& Doerr 2006). Moreover, coarsetextured soils, as found at our study sites, typically have low available water content; thus, small variations may significantly affect plant growth (Albanesi \& Anriquez 2003; Thompson \& Troeh 1988). Decreased soil water content in frequently burned sites can directly lower
SLA as a way of maximizing the limited and scarce water available with a conservative resource use strategy (Pérez-Ramos et al. 2012). Furthermore, decreased EC as a result of high fire frequency results from reduced inorganic ions from the soil's cation exchange capacity (extractable $\mathrm{Mg}$ and $\mathrm{Ca}$ ), which are essential plant nutrients (Brye 2006). In contrast, total soil N, P, organic C and $\mathrm{C}: \mathrm{N}$ did not significantly change across burned and unburned sites. These soil characteristics have been observed to be rough proxies of nutrient supply to the vegetation, because most nutrient stocks can be occluded in recalcitrant forms (Aerts \& Chapin 2000). Mineralized forms of nitrogen, such as nitrates, together 

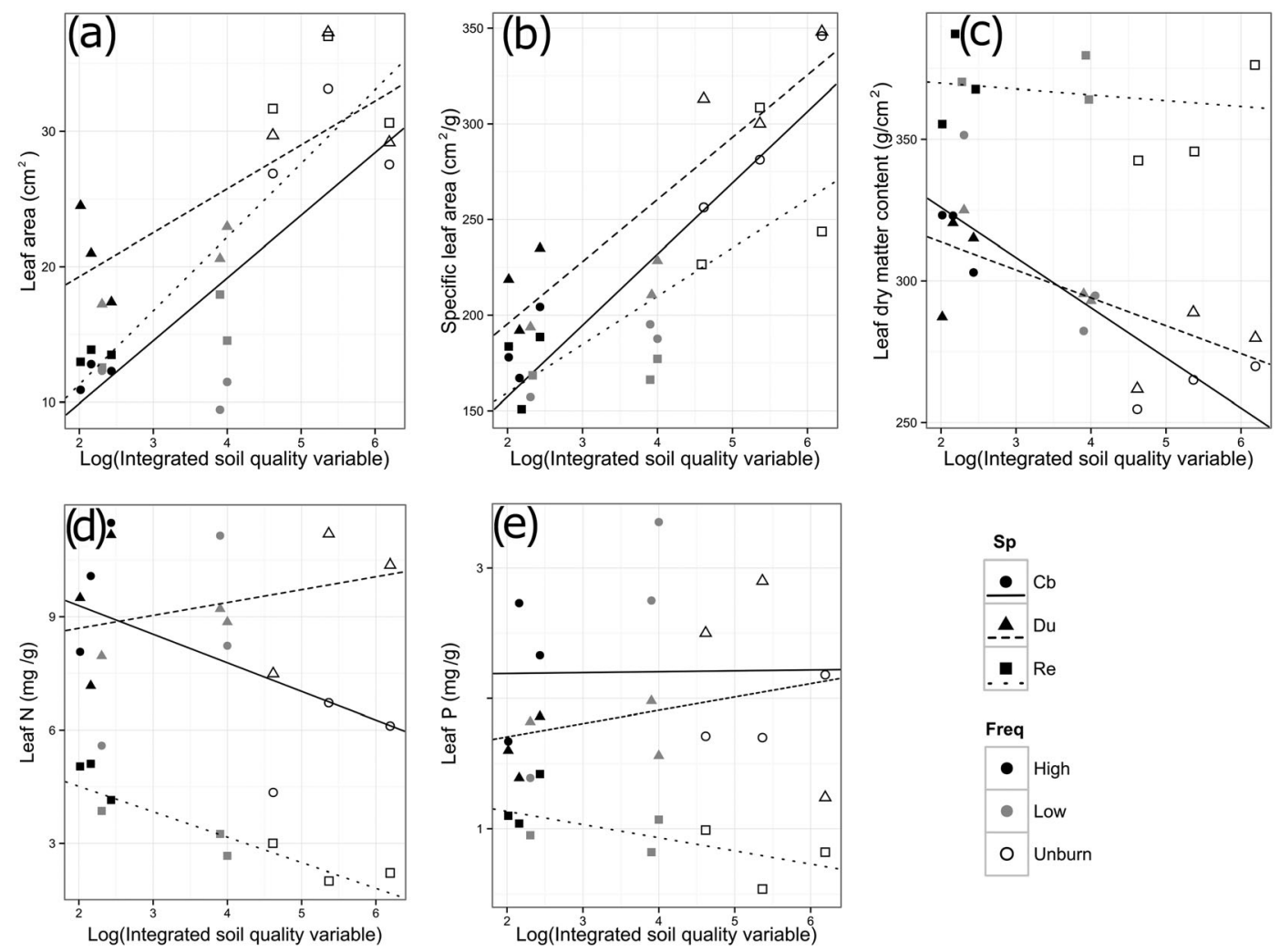

Fig. 4. Relationships of the average leaf area (a), specific leaf area (b), leaf dry matter content (c), leaf nitrogen (d) and leaf phosphorous (e) with the integrated soil quality variable (log transformed) in unburned scenarios (white dots), low fire frequency (grey dots) and high fire frequency (black dots) for Cologania broussonetii (Cb, circle), Desmodium uncinatum (Du, triangle) and Rhynchosia edulis (Re, square). Each data point is the average value of leaf traits per species and soil quality parameters per site $(N=9)$; in certain cases identical values overlap data points.

with the controlling factors of nutrient cycling, such as soil moisture and texture, may be better proxies of plant nutrient supply (Aerts \& Chapin 2000; Ordoñez et al. 2009). This may be the situation in our low and high fire frequency scenarios, where available water and nitrates for plants to absorb were seriously compromised, lowering LA and SLA trait values and increasing levels of LDMC consistently in the three studied species. This is the first study to our knowledge that assessed soil quality and intraspecific variability in plant functional traits in different fire frequency conditions. An assessment of fire recurrence on plant functional traits has been documented at the intraspecific level in the Cerrado ecosystem but they did not evaluate soil quality parameters (Loiola et al. 2010; Cianciaruso et al. 2012; Dantas et al. 2013a). These studies concur with our findings of decreased LA and SLA as fire frequency increased. However, these authors also found decreased plant nutrients with increased fire frequency, which contrasts with our results. At the interspecific level, the three studied species responded similarly, which is expected when species are phylogenetically closely related and share similar life-history traits, as observed elsewhere (Anacker et al. 2011; Dantas et al. 2013b).
Many Fabaceae species have different strategies to cope in nutrient-stressed environments, maintaining optimal levels of main nutritional traits with key implications for ecosystem functioning (Carreira \& Niell 1992; Goergen \& Chambers 2009). For example, long-lived resprouter plants, such as these three native Fabaceae species, have a conservative use of nutrients and allocate more resources to underground organs such as rhizomes, which facilitates regrowth (Saura-Mas \& Lloret 2009). Moreover, in resprouter plants, fire eliminates aerial biomass while roots survive. Thus, high fire recurrence increases root:above-ground biomass ratios, allowing resprouters to reach higher foliar nutrient concentrations, regardless of nutrient uptake efficiency or soil fertility (Chapin 1980; Carreira \& Niell 1992). An additional mechanism for maintaining and even increasing $\mathrm{N}$ leaf nutrient content in particular with increasing fire frequency in these three species can be related to their biological $\mathrm{N}_{2}$-fixation capability. In fact, increased light availability after fire and decreased nitrates in frequent burned sites may favour biological $\mathrm{N}_{2}$ fixation, enhancing the rate of $\mathrm{N}_{2}$ fixation and thereby of plant $\mathrm{N}$ content (Carreira \& Niell 1992; Casals et al. 2005; Goergen \& Chambers 2009). Around 20\% of Fabaceae 

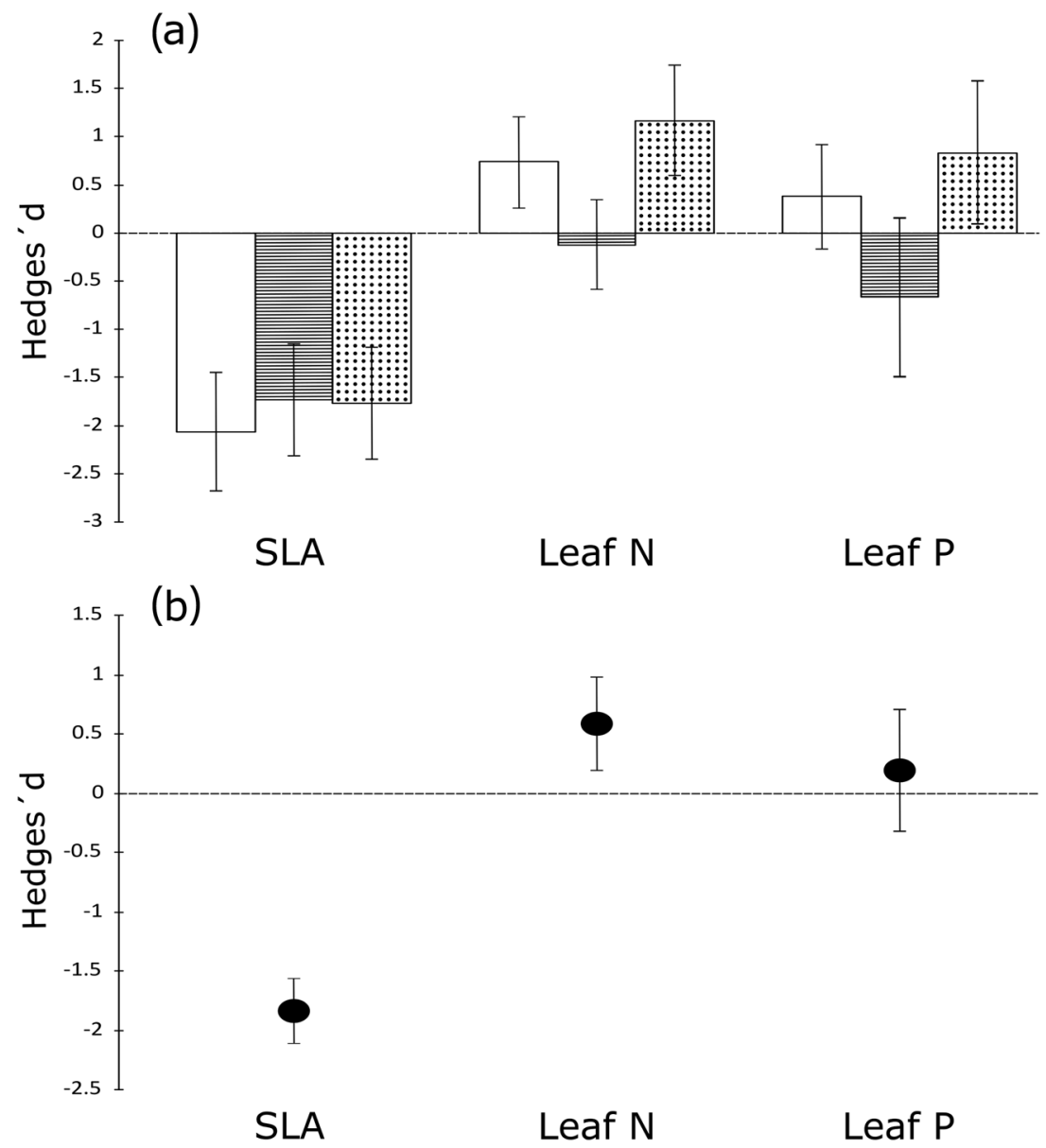

Fig. 5. Interspecific (a) and overall (b) responses of increased fire frequency on specific leaf area (SLA), leaf nitrogen (N) and leaf phosphorous $(\mathrm{P})$. Values are mean and $95 \%$ confidence intervals. Cologania broussonetii (white), Desmodium uncinatum (horizontal strips) and Rhynchosia edulis (dotted). Dotted line denotes Hedges's $d=0$. Mean values with confidence intervals overlapping cero imply that they are not significantly different from cero.

species are known to establish a symbiotic relationship with $\mathrm{N}_{2}$-fixing Rhizobium bacteria (Sprent \& Sprent 1990), and Fabaceae usually show higher frequency, density and diversity of species in post-fire scenarios as a result of their biological $\mathrm{N}_{2}$-fixation capability ( Hendricks \& Boring 1999; Guinto et al. 2000). For example, species of the genus Rhynchosia (Fabaceae) increased levels of biological $\mathrm{N}_{2}$ fixation after fire, showing a positive association between absorbed $\mathrm{N}$ from the atmosphere and total biomass per plant (Hiers \& Mitchell 2007). Such responses can be expected because soil mineral deficiencies rarely affect biological $\mathrm{N}_{2}$-fixation rates (Raison 1979; Aranibar et al. 2003); in contrast, high soil $\mathrm{N}$ availability produces a negative effect on nodulation (Casals et al. 2005), presumably to reduce the high energetic cost of biological $\mathrm{N}_{2}$ fixation (Aerts \& Chapin 2000).

When plant species with biological $\mathrm{N}_{2}$ fixation have high $\mathrm{N}$ content in their leaves, they may contribute to enriching the underground environment through root exudates and decomposition of their tissues (Casals et al. 2005; Reverchon et al. 2012). In sites with low fertility occasioned by recurrent fires, even low rates of biological $\mathrm{N}_{2}$ fixation may represent a valuable source for restoring soil $\mathrm{N}$ levels (Raison 1979; Caon et al. 2014). Thus, biological $\mathrm{N}_{2}$ fixation represents a key functional trait for restoring soil nutrient cycling in degraded burned areas as has been shown in a few Fabaceae such as Cologania, Rhynchosia and Lupinus (Hiers et al. 2003; Goergen \& Chambers 2009; Grau et al. 2009). By maintaining or increasing nutrients in their tissue in burned scenarios, these native species can shape successional dynamics and contribute to nutrient cycling in post-fire microenvironments, improving abiotic conditions and allowing other species to emerge. However, transferring nutrients back to the soil requires time periods long enough to cycle $\mathrm{N}$ and $\mathrm{P}$ through litterfall (Reverchon et al. 2012). Thus, active management of burned areas is needed to allow sufficient time for the completion of nutrient cycling to restore soil fertility, which may vary depending on the system. 
Over the past decades, there has been a net increase of wildfires and burned areas in certain subtropical and temperate regions, such as forests from eastern Australia (Bradstock 2010) and the Chaco region in central Argentina (Kunst \& Bravo 2003; Bravo et al. 2010). Because fire operates as an ecological filter, such changes in fire regime can significantly alter plant community structure and composition, selecting species with particular combinations of morphological and functional traits (Bradstock 2010; Keeley et al. 2011). Thus, plant species with fire-persistence traits are selected and overrepresented in frequently burned communities, thereby delimiting the species composition and plant functional diversity found in a given community (Pausas \& Verdú 2008). Currently, as a result of increased frequent fires, many forest ecosystems around the globe are being driven towards savannas, increasing the dominance of herbaceous species and reducing shrub and tree layers (e.g. Bradstock 2010). A similar process is likely to be occurring in our studied burned sites, where the plant community is mostly dominated by herbaceous species. In fact, in burned sites, there is less than $50 \%$ of the shrub and tree species found in unburned sites (Carbone 2015). Shrub and tree species remaining in these burned scenarios also share common life-history traits such as resprouting (e.g. L.molleoides, Celtis ehrenbergiana, Condalia spp., Baccharis spp.), and nitrogen-fixing capacities (e.g. Acacia spp, Geoffroea decorticans). Therefore, quality-depleted and drier soils that result from increased fire frequencies in the Chaco Serrano region may not only affect trait variation at the intraspecific level, but can also drive the community to a predominance of plant species with conservative resource-use strategies (Pérez-Ramos et al. 2012; Reverchon et al. 2012). Such processes will lead to a homogenization of the community where slow-growing, resprouter plant species with reduced and sclerophyllous leaves, and a more efficient use of water will be favoured and predominate against fast-growing species, with broad leaves and acquisitive resource-use strategies. In the end, these plant community level changes triggered by recurrent fire will affect important ecosystem processes such as litter decomposition and productivity (Díaz et al. 1999; Anacker et al. 2011).

\section{ACKNOWLEDGEMENTS}

We truly appreciate the critical and constructive comments made by three anonymous referees and the subject editor, who helped to improve the final version of this manuscript. We are grateful to Matías A. Castillo Moine, Julia L. Camina, Cesar Carballo and Matías L. Sotomayor for fieldwork assistance; to Melisa A. Giorgis and Juan P. Argañaraz for providing the geographical information, which allowed us the selection of the studied sites; and to proprietors of fields for their permission and provided information. We thank Elsa Fuentes, Ramiro Lascano and Juli G. Pausas for their valuable comments on early drafts. This work was supported by the Science and Technology Secretary of the Faculty of Agronomic Sciences (UNC) (PROIINDIT RD-850-2013), the Science and Technology Secretary of the National University of Córdoba (05/G457), CONICET (PIP 0019) and FONCyT (PICT 2011-1606). L.M.C. is a fellowship holder of CONICET and R.A. is a researcher of the same institution.

The authors declare that they have no conflict of interest.

\section{REFERENCES}

Aerts R. \& Chapin F. S. III (2000) The mineral nutrition of wild plants revisited: a re-evaluation of processes and patterns. Adv. Ecol. Res. 30, 1-67.

Aguirre-Acosta N., Kowaljow E. \& Aguilar R. (2014) Reproductive performance of the invasive tree Ligustrum lucidum in a subtropical dry forest: does habitat fragmentation boost or limit invasion? Biol. Invasions 16, 1397-410.

Albanesi A. \& Anriquez A. (2003) El fuego y el suelo. In: Fuego en los ecosistemas Argentinos (eds C. R. Kunst, S. Bravo \& J. L. Panigatti) pp. 47-59. INTA, Santiago del Estero, Arg.

Albert C. H., Thuiller W., Yoccoz N. G., et al. (2010) Intraspecific functional variability: extent, structure and sources of variation. F. Ecol. 98, 604-13.

Anacker B., Rajakaruna N., Ackerly D., Harrison S., Keeley J. \& Vasey M. (2011) Ecological strategies in California chaparral: interacting effects of soils, climate, and fire on specific leaf area. Plant Ecol. Divers. 4 (2-3), 179-88.

Aranibar J. N., Macko S. A., Anderson I. C., Potgieter A. L. F., Sowry R. \& Shugart H. H. (2003) Nutrient cycling responses to fire frequency in the Kruger National Park (South Africa) as indicated by stable isotope analysis. Isot. Environ. Health. S. 39 (2), 141-58.

Argañaraz J. P., Pizarro G. G., Zak M., Landi M. A. \& Bellis L. M. (2015a) Human and biophysical drivers of fires in semiarid Chaco mountains of central Argentina. Sci. Total Environ. 520, 1-12.

Argañaraz J. P., Pizarro G. G., Zak M. \& Bellis L. M. (2015b) Fire regime, climate, and vegetation in the Sierras de Córdoba, Argentina. Fire Ecology 11 (1), 55-73.

Bates D., Maechler M., Bolker B. \& Walker S. (2014) lme4: linear mixed-effects models using Eigen and S4. R package version 1.1-7, URL: http://CRAN.R-project.org/ package $=1 \mathrm{me} 4$.

Bond W. J., Woodward F. I. \& Midgley G. F. (2005) The global distribution of ecosystems in a world without fire. New Phytol. $165,525-38$.

Bradstock R. A. (2010) A biogeographic model of fire regimes in Australia: current and future implications. Global Ecol. Biogeogr. 19, 145-58.

Bravo S., Kunst C., Gimenez A. \& Moglia G. (2001) Fire regime of a Elionorus muticus Spreng. savanna, western Chaco region, Argentina. Int. F. Wildland Fire 10, 65-72.

Bravo S., Kunst C., Grau R. \& Aráoz E. (2010) Fire-rainfall relationships in Argentine Chaco savannas. F. Arid Environ. 74, 1319-23.

Brye K. R. (2006) Soil physiochemical changes following 12 years of annual burning in a humid-subtropical tallgrass prairie: a hypothesis. Acta Oecologica 30, 407-13. 
Cabido M., Giorgis M. A. \& Tourn M. (2010) Guía para una excursión botánica en las sierras de Córdoba. Bol. Soc. Argent. Bot. 45 (1-2), 209-19.

Cabrera A. L. (1971) Fitogeografía de la República Argentina. Bol. Soc. Argent. Bot. 14 (1-2), 1-42.

Caon L., Vallejo V. R., Coen R. J. \& Geissen V. (2014) Effects of wildfire on soil nutrients in Mediterranean ecosystems. Earth-Sci. Rev. 139, 47-58.

Carbone L. M., Aguilar R. \& Fuentes E. (2013) Caracteres funcionales y herbivoría en Fabaceae nativas forrajeras en relación al fuego. Bol. Soc. Argent. Bot. 48 (Supl), 63.

Carbone L. M. (2015) Ecología reproductiva de Fabaceae nativas forrajeras en diferentes escenarios post-fuego de las Sierras Chicas de Córdoba (Argentina). Tesis Doctoral en desarrollo. National University of Cordoba, Argentina.

Carreira J. A. \& Niell F. X. (1992) Plant nutrient changes in a semiarid Mediterranean shrubland after fire. F. Veg. Sci. 3, 457-66.

Casals P., Romanyà J. \& Vallejo V. R. (2005) Short-term nitrogen fixation by legume seedlings and resprouts after fire in Mediterranean old-fields. Biogeochemistry 76, 477-501.

Certini G. (2005) Effects of fire on properties of forest soils: a review. Oecologia 143, 1-10.

Chapin F. S. III (1980) The mineral nutrition of wild plants. Annu. Rev. Ecol. Syst. 11, 233-60.

Cianciaruso M. V., Silva I. A., Batalha M. A., Gaston K. J. \& Petchey O. L. (2012) The influence of fire on phylogenetic and functional structure of woody savannas: moving from species to individuals. Perspect. Plant. Ecol. 14, 205-16.

Dantas V. L., Pausas J. G., Batalha M. A., de Loiola P. P. \& Cianciaruso M. V. (2013a) The role of fire in structuring trait variability in Neotropical savannas. Oecologia 171, 487-94.

Dantas V. L., Batalha M. A. \& Pausas J. G. (2013b) Fire drives functional thresholds on the savanna-forest transition. Ecology 94 (11), 2454-63.

Davies G. M. (2013) Understanding fire regimes and the ecological effects of fire. In: Fire Phenomena and the Earth System: An Interdisciplinary Guide to Fire Science, 1st edn (ed C. M. Belcher) pp. 95-124. John Wiley \& Sons Ltd. Published, UK.

Díaz S., Cabido M. \& Casanoves F. (1998) Plant functional traits and environmental filters at a regional scale. f. Veg. Sci. 9 (1), 113-22.

Díaz S., Cabido M., Zak M., Carretero E. M. \& Araníbar J. (1999) Plant functional traits, ecosystem structure and land-use history along a climatic gradient in central-western Argentina. f. Veg. Sci. 10, 651-60.

Fortunato R. H. (1983) Sinopsis de las Especies Argentinas del Genero Rhynchosia. Parodiana 2 (1), 25-58.

Fuentes E., Carreras M. E., Carbone L. M., Jewsbury G., Loyola M. J. \& Martinat J. E. (2011) Especies nativas de las Sierras Chicas (Córdoba, Argentina) con estrategias de regeneración post-fuego. Bol. Soc. Argent. Bot. 46 (Supl), 192.

Giorgis M. A., Cingolani A. M., Chiarini F., et al. (2011) Composición florística del Bosque Chaqueño Serrano en la provincia de Córdoba, Argentina. Kurtziana 36 (1), 9-43.

Giorgis M. A., Cingolani A. M. \& Cabido M. (2013) El efecto del fuego y las características topográficas sobre la vegetación y las propiedades del suelo en la zona de transición entre bosques y pastizales de las sierras de Córdoba, Argentina. Bol. Soc. Argent. Bot. 48 (3-4), 493-513.

Goergen E. M. \& Chambers J. C. (2009) Influence of a native legume on soil $\mathrm{N}$ and plant response following prescribed fire in sagebrush steppe. Int. F. Wildland Fire 18, 665-75.

González-Pelayo O., Gimeno-García E., Ferreira C. S. S., et al. (2015) Water repellency of air-dried and sieved samples from limestone soils in central Portugal collected before and after prescribed fire. Plant Soil. 394 (1), 199-214.

Grau G., Yates R. J., Deiana P. \& Howieson J. G. (2009) Novel strains of nodulating Burkholderia have a role in nitrogen fixation with papilionoid herbaceous legumes adapted to acid, infertile soils. Soil Biol. Biochem. 41, 125-34.

Guinto D. F., Xu Z. H., House A. P. N. \& Saffigna P. G. (2000) Assessment of $\mathrm{N}_{2}$ fixation by understorey acacias in recurrently burnt eucalypt forests of subtropical Australia using $15 \mathrm{~N}$ isotope dilution techniques. Can. F. For. Res. 30, 112-21.

Hendricks J. L. \& Boring L. R. (1999) $\mathrm{N}_{2}$-fixation by native herbaceous legumes in burned pine ecosystems of the southwestern United States. For. Ecol. Manage. 113, 167-77.

Hiers J. K., Mitchell R. J., Boring L. R., Hendricks J. J. \& Wyatt R. (2003) Legumes native to longleaf pine savannas exhibit capacity for high $\mathrm{N}_{2}$-fixation rates and negligible impacts due to timing of fire. New Phytol. 157, 327-38.

Hiers J. K. \& Mitchell R. J. (2007) The influence of burning and light availability on $\mathrm{N}_{2}$-fixation of native legumes in longleaf pine woodlands. F. Torrey Bot. Soc. 134 (3), 398-409.

Howard P. J. A. \& Howard D. M. (1990) Use of organic carbon and loss on ignition to estimate soil organic matter in different soil types and horizons. Biol. Fert. Soils 9, 306-10.

Keeley J. E., Pausas J. G., Rundel P. W., Bond W. J. \& Bradstock R. A. (2011) Fire as an evolutionary pressure shaping plant traits. Trends Plant Sci. 16 (8), 406-411.

Koricheva J., Gurevitch J. \& Mengersen K. (2013) Handbook of Meta-Analysis in Ecology and Evolution. Princeton University Press, Princeton, Princeton and Oxford.

Kunst C. R. \& Bravo S. (2003) Ecología y régimen de fuego en la región chaqueña argentina. In: Fuego en los ecosistemas Argentinos (eds C. R. Kunst, S. Bravo \& J. L. Panigatti) pp. 47-59. INTA, Santiago del Estero, Arg.

Loiola P. P., Cianciaruso M. V., Silva I. A. \& Batalha M. A. (2010) Functional diversity of herbaceous species under different fire frequencies in Brazilian savannas. Flora 205, 674-81.

Luti R., Bertran de Solis M. A., Galera M. F., et al. (1979) Vegetación. In: Geografía física de la provincia de Córdoba (eds J. B. Vázquez, R. A. Miatello \& M. E. Roqué) pp. 297-368. Editorial Boldt, Buenos Aires, Arg.

Miglietta S. (1994) Patrón de ocurrencia de fuegos y su efecto sobre la vegetación en el bosque Serrano de Córdoba. Tesis de Maestría, Facultad de Cs. Ex. Fís. y Nat., Universidad Nacional de Córdoba, Argentina.

Moreira B., Tavsanoglu C.. \& Pausas J. G. (2012) Local vs regional intraspecific variability in regeneration traits. Oecologia 168, 671-7.

Ojeda F., Pausas J. G. \& Verdú M. (2010) Soil shapes community structure through fire. Oecologia 163, 729-35.

Ordoñez J. C., van Bodegom P. M., Witte J. P. M., Wright I. J., Reich P. B. \& Aerts R. (2009) A global study of relationships between leaf traits, climate and soil measures of nutrient fertility. Global Ecol. Biogeogr. 18, 137-49.

Paula S. \& Pausas J. G. (2006) Leaf traits and resprouting ability in the Mediterranean basin. Funct. Ecol. 20, 941-7.

Pausas J. G., Bradstock R. A., Keith D. A., Keeley J. E. \& GCTE (2004) Plant functional traits in relation to fire in crown-fire ecosystems. Ecology 85 (4), 1085-100.

Pausas J. G. \& Keeley J. E. (2009) A burning story: the role of fire in the history of life. BioScience 59 (7), 598-601.

Pausas J. G. \& Verdú M. (2008) Fire reduces morphospace occupation in plant communities. Ecology 89 (8), 2181-86.

Pellegrini A. F. A., Hedin L. O., Staver A. C. \& Govender N. (2015) Fire alters ecosystem carbon and nutrients but not plant 
nutrient stoichiometry or composition in tropical savanna. Ecology 96 (5), 1275-85.

Pérez-Harguindeguy N., Diaz S., Garnier E., et al. (2013) New handbook for standardised measurement of plant functional traits worldwide. Aust. F. Bot. 61 (3), 167-234.

Pérez-Ramos I. M., Roumet C., Cruz P., Blanchard A., Autran P. \& Garnier E. (2012) Evidence for a 'plant community economics spectrum' driven by nutrient and water limitations in a Mediterranean rangeland of southern France. f. Ecol. $100,1315-27$

Pinheiro J., Bates D., Debroy S., Sarkar D. \& The R Core team (2009) nlme: linear and nonlinear mixed effects models. $R$ package version 3, 1-96.

Prado-Júnior J., Schiavini I., Vale V., Lopes S., Arantes C. \& Oliveira A. P. (2015) Functional leaf traits of understory species: strategies to different disturbance severities. Braz. F. Biol. 75 (2), 339-46.

R Core Team (2015) R: A Language and Environment for Statistical Computing. R Foundation for Statistical Computing, Vienna, Austria. Available from URL http://www.R-project.org/

Raison R. J. (1979) Modification of the soil environment by vegetation fires, with particular reference to nitrogen transformations: a review. Plant Soil 51, 73-108.

Reverchon F., Xu Z., Blumfield T. J., Chen C. \& Abdullah K. M. (2012) Impact of global climate change and fire on the occurrence and function of understorey legumes in forest ecosystems. F. Soils Sediments 12, 150-60.
Rosbakh S., Romermann C. \& Poschlod P. (2015) Specific leaf area correlates with temperature: new evidence of trait variation at the population, species and community levels. Alp. Botany 125 (2), 79-86.

Saura-Mas S. \& Lloret F. (2009) Linking post-fire regenerative strategy and leaf nutrient content in Mediterranean woody plants. Perspectives Plant Ecol. 11, 219-29.

Shakesby R. A. \& Doerr S. H. (2006) Wildfire as a hydrological and geomorphological agent. Earth-Sci. Rev 74, 69-307.

Sprent J. I. \& Sprent P. (1990) Nitrogen Fixing Organisms. Pure and Applied Aspects. Chapman and Hall, London.

Thompson L. M. \& Troeh F. R. (1988) El agua del suelo. In: Los suelos y su fertilidad (eds L. M. Thompson \& F. R. Troeh) pp. 99-134. Reverté, Barcelona, España.

Vanni R. O. (2001) El género Desmodium (Leguminosae-Desmodieae) en Argentina. Darwiniana 39 (3-4), 255-85.

Wan S., Hui D. \& Luo Y. (2001) Fire effects on nitrogen pools and dynamics in terrestrial ecosystems: a meta-analysis. Ecol. Appl. 11 (5), 1349-65.

Wang Q., Zhong M. \& Wang S. (2012) A meta-analysis on the response of microbial biomass, dissolved organic matter, respiration, and $\mathrm{N}$ mineralization in mineral soil to fire in forest ecosystems. Forest Ecol. Manag. 271, 91-7.

Whelan R. J. (1995) The Ecology of Fire. Cambridge University Press, Cambridge, UK. 